\title{
Penetration of 99 Richter Grapevine Roots by Phytophthora cinnamomi*
}

\author{
P. G. MARAIS AND A. C. DE LA HARPE \\ Oenological and Viticulture Research Institute, Private Bag X5026, Stellenbosch 7600. \\ The authors thank Prof. M. J. Hattingh for advice in the preparation of the manuscript, Mrs. H. A. Keyser for technical assistance and Mr. M. van \\ Dijk, Department of Physics, University of Stellenbosch, for the electron micrographs.
}

Submitted for publication: September 1982.

Accepted for publication: October 1982

\begin{abstract}
The mechanism of penetration of 99 Richter grapevine roots by Phytophthora cinnamomi was studied by light, scanning and transmission electron microscopy. Zoospores encysted on roots within 30 min after inoculation. More spores encysted and germinated near roots than further away, indicating a response to some stimulus exuded by the roots. Germ tubes were usually not swollen at the point of entry into the roots. Penetration occurred mostly down the anticlinal walls separating epidermal cells and hyphae developed intercellularly. Swollen germ tubes were sometimes observed where intracellular hyphal growth was preceded by direct penetration of epidermal cells. Some evidence of hydrolysis of epidermal cell walls was found, whereas hydrolysis of cortical cell walls occurred more frequently. Shortly after penetration a plug of amorphous material formed in the germ tube sealing off the penetration peg within the roots. Within 48 hours after inoculation hyphae were observed in the endodermis. Invaded epidermal, cortical and endodermal cells were disrupted and underwent plasmolysis.
\end{abstract}

Phytophthora cinnamomi Rands is the causal agent of root rot associated with the decline and ultimate death of grapevines grafted on 99 Richter (Van der Merwe, Joubert \& Matthee, 1972; Marais, 1978a). Different grapevine rootstock cultivars have been shown, both in the field and pot trials, to vary in susceptibility to $P$. cinnamomi (Marais, 1979). The pathogen apparently attacks susceptible as well as tolerant rootstock (Marais, 1978b), but the mechanism of penetration and infection in grapevine roots is largely unknown. Additional information is required to broaden existing knowledge of resistance to P. cinnamomi. Infection and penetration of 99 Richter roots by $P$. cinnamomi zoospores and vegetative hyphae were, therefore, studied.

\section{MATERIAL AND METHODS}

Zoospore production: To obtain sporangia of $P$. cinnamomi an isolate from grapevine roots was initially cultured on potato dextrose agar. Inoculum disks were cut from the advancing margin of the culture after $7 \mathrm{~d}$, placed in petri dishes containing V-8 juice broth (Chen \& Zentmyer, 1970 ) and incubated for $2 \mathrm{~d}$ at $25^{\circ} \mathrm{C}$. The resulting mycelial growth was washed with sterile distilled water and incubated at $20^{\circ} \mathrm{C}$ in petri dishes containing liquid soil extract (James, 1958). To achieve synchronized release of zoospores, mycelia bearing sporangia were chilled at $10^{\circ} \mathrm{C}$ for $15 \mathrm{~min}$ and returned to room temperature. Zoospore concentration was determined with a haemacytometer.

Preparation and inoculation of plant material: Lengths $(40 \mathrm{~mm})$ of actively growing shoots were cut from 99 Richter grapevines, surface-sterilized in $0,5 \%$ sodium hypochlorite, washed in sterile distilled water, transferred aseptically onto filter paper bridges in $2,5 \mathrm{~cm}$ diameter test tubes containing $0,5 \%$ Hoagland's nutrient solution, and incubated at $22^{\circ} \mathrm{C}$ to induce root formation.

Root tips (20-30 mm) were excised from rooted shoots, washed in distilled water and placed in a suspension containing $10^{2}$ zoospores $/ \mathrm{m} \ell$ in an observation cell designed by Khew \& Zentmyer (1973). The number of encysted and

* Part of a Ph.D. (Agric) thesis to be submitted by the senior author to the University of Stellenbosch, Stellenbosch 7600 germinating zoospore cysts present in $0,5 \mathrm{~mm}$ zones extending $2 \mathrm{~mm}$ from the root surface was determined microscopically (100 X).

Each test tube containing rooted shoots was inoculated with $30 \mathrm{~m} \ell$ of the zoospore suspension $\left(10^{2}\right.$ zoospores $\left./ \mathrm{m} \ell\right)$. Control tubes received $30 \mathrm{~m} \ell$ distilled water. For observation of vegetative hyphal penetration, roots were placed on water agar plates containing $3 \mathrm{~d}$ old $P$. cinnamomi colonies and incubated in the dark at $25^{\circ} \mathrm{C}$.

Light and electron microscopy: Root specimens for light and electron microscopy were removed at intervals, $2-12 \mathrm{~h}$ after inoculation.

For scanning electron microscopy, root sections $(1 \mathrm{~mm}$ long) were dissected from the inoculated roots and fixed in $4 \%$ glutaraldehyde, $(\mathrm{pH} 4)$, for $24 \mathrm{~h}$ at $4^{\circ} \mathrm{C}$. The roots were afterwards washed twice for 15 min periods in a 0,2 $M$ sodium cacodylate buffer $(\mathrm{pH} 7,2)$, dehydrated in a graded acetone-water series, subjected to critical point drying with $\mathrm{CO}_{2}$ and coated with a gold-palladium alloy.

For light and transmission electron microscopy, root sections ( $1 \mathrm{~mm}$ long) were fixed for $4 \mathrm{~h}$ in $6 \%$ glutaraldehyde, buffered to $\mathrm{pH} 7,2$ in $0,2 \mathrm{M}$ sodium cacodylate. The sections were postfixed for $12 \mathrm{~h}$ in $1 \%$ sodium tetroxide and subsequently dehydrated through the acetone-water series.

Tissue was infiltrated with $30 \%$ and $60 \%$ spurr/acetone mixtures for $6 \mathrm{~h}$ periods, followed by Spurr's mixture for $24 \mathrm{~h}$. The material was embedded in Spurr's epoxy resin (Spurr. 1969) and polymerized at $70^{\circ} \mathrm{C}$ for $8 \mathrm{~h}$. Sections for electron microscopy were cut on a Reichert ultramicrotome and stained with $4 \%$ uranyl acetate and lead citrate (Reynolds, 1963). Sections $(2,0 \mu \mathrm{m})$ for light microscopy were stained with $0,2 \%$ toluidine blue, $\mathrm{pH} 9,0$.

\section{RESULTS AND DISCUSSION}

Zoospores were clustered around the zone of root elongation within $30 \mathrm{~min}$ of exposure to the zoospore suspension. After $30 \mathrm{~min}$, more zoospores could be found in the zones closest to the roots (Table 1). More zoospores encysted and germinated on and near the root than further away and germ tubes were directed towards the root (Fig. 1). 


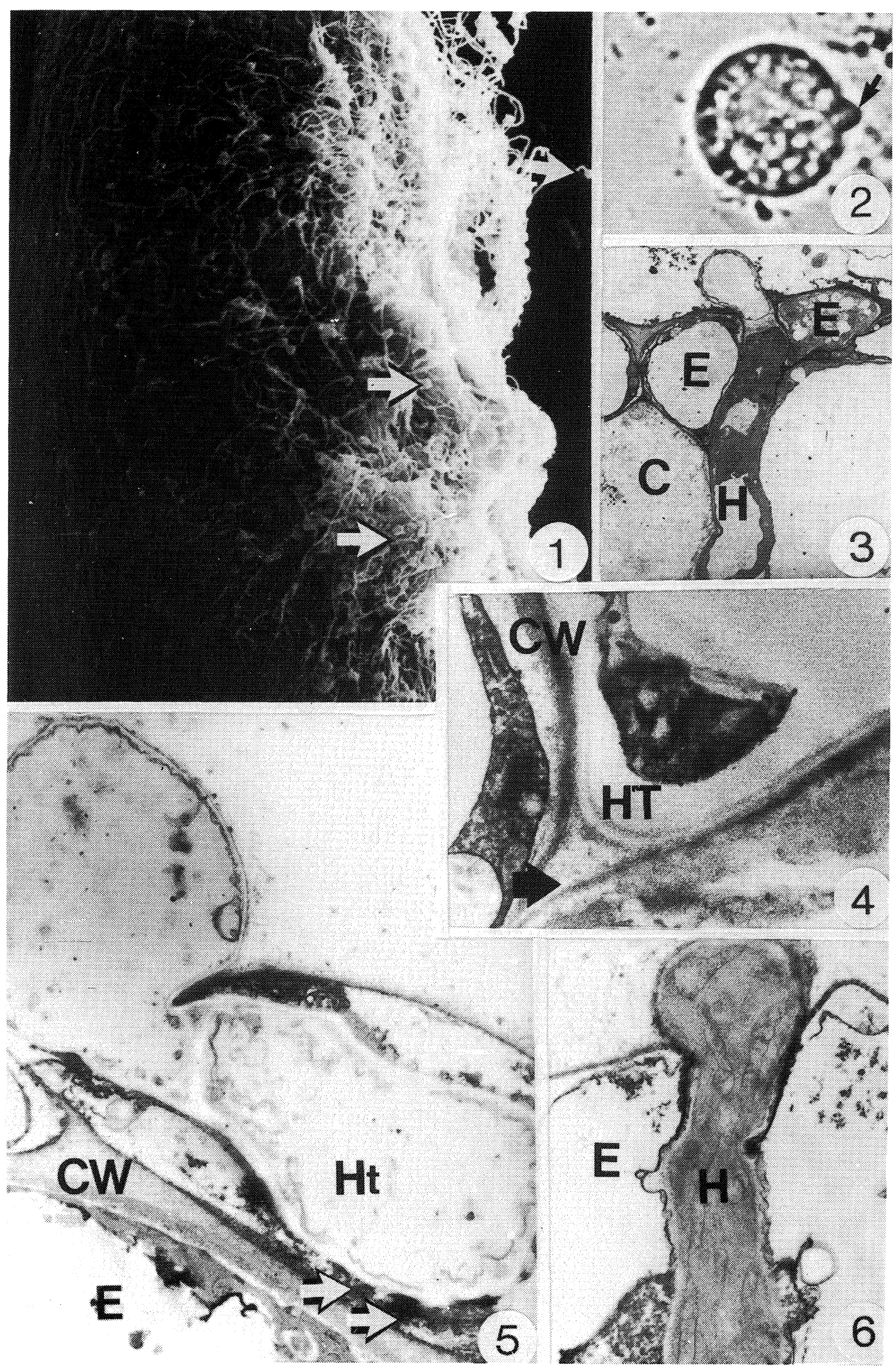

Figs. 1-6.

Penetration and infection of 99 Richter grapevine roots by Phytophthora cinnamomi. 1. Scanning electron micrograph of zoospores and germinating zoospore cysts (arrows) clustered around a root $30 \mathrm{~min}$ after inoculation (X 180). 2. Light micrograph of a zoospore cyst with the beginning of a germ tube (arrow) (X 250). 3. Transmission electron micrograph of penetration from a zoospore infection hyphae $(\mathrm{H})$ between two epidermal cells $(\mathrm{E})$ and cortical cells $(\mathrm{C})(\mathrm{X} 4000)$. 4. Transmission electron micrograph of the intercellular cleavage (arrow) of cortical cell walls (CW) by the invading hyphal tip (HT) (X3 000). 5. Transmission electron micrograph of granular material (arrows) formed between the zoospore germ tube (Ht) and the cell wall $(\mathrm{CW})$ of an epidermal cell (E) (X15 000). 6. Transmission electron micrograph of direct penetration of an epidermal cell (E) by an infection hypha (H) (X8 500) 

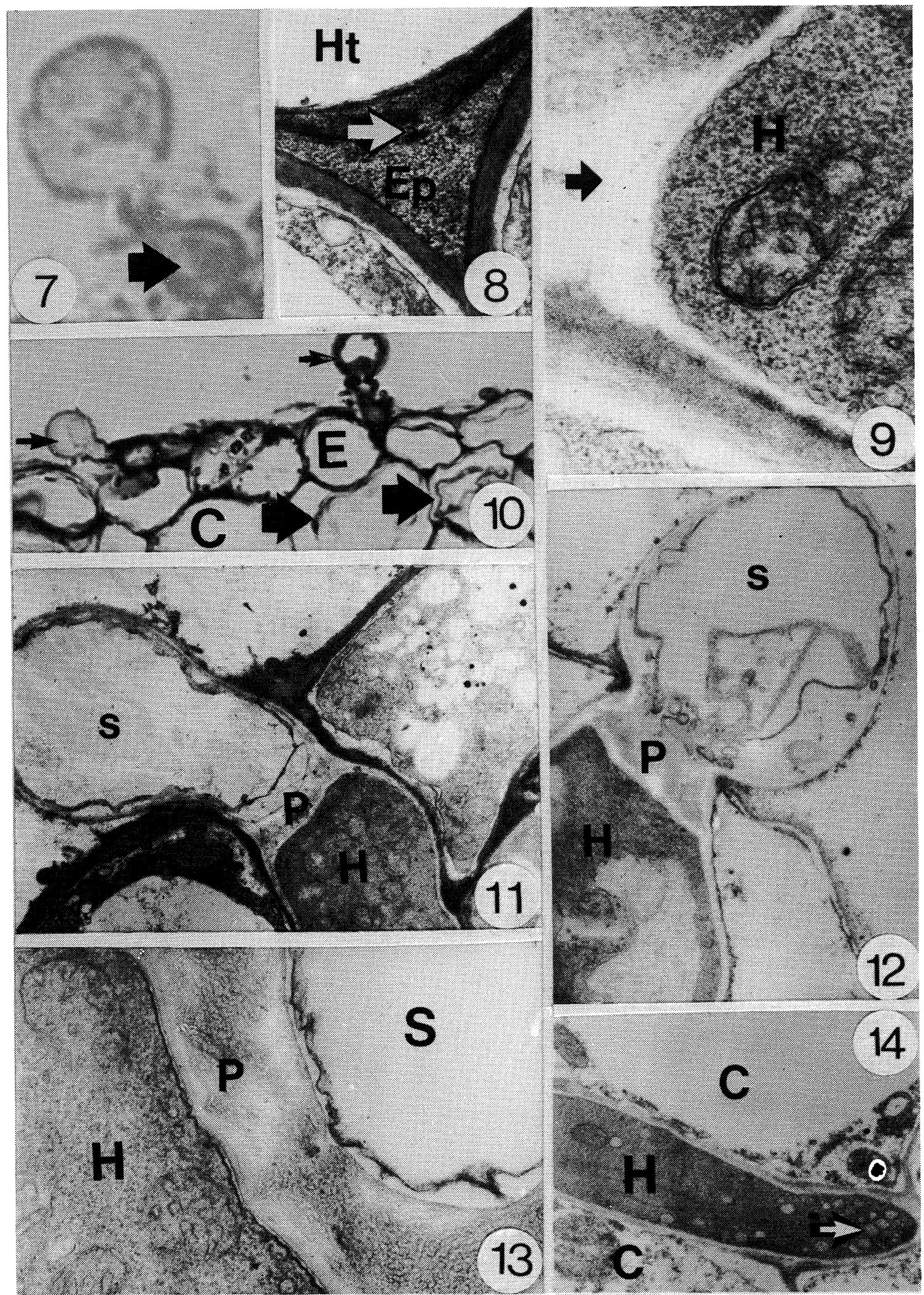

Figs. $7-14$

Penetration and infection of 99 Richter grapevine roots by Phytophthora cinnamomi. 7. Light micrograph of a swelling (arrow) formed by the germ tube at the point of contact with the epidermal cell (X 250). 8. Transmission electron micrograph of the thickening of the germ tube (Ht) wall (arrow) at the point of contact with the root epidermis (EP) (X 30000 ). 9. Transmission electron micrograph of hydrolysis of cortical cell walls (arrow) in advance of an infection hypha (H) (X 36 000). 10. Light micrograph of penetration of epidermal cells (E). Zoospore cysts had become vacuolate (small arrows) while infection hyphae (large arrows) are evident between the the cortical cells (C) (X 150). 11. Transmission electron micrograph of zoospore penetration. A plug $(\mathrm{P})$ is present between the empty cyst $(\mathrm{S})$ and the infection hypha $(\mathrm{H})(\mathrm{X} \mathrm{12}$ 000). 12. Transmission electron micrograph of a nearly empty zoospore cyst $(S)$ and a plug $(P)$ sealing the cyst from the internal infection hypha $(H)(X 19000)$. 13. Transmission electron micrograph of the plug $(\mathrm{P})$ formed between the empty cyst $(\mathrm{S})$ and the infection hypha $(\mathrm{H})(\mathrm{X} 40000)$. 14. Transmission electron micrograph of an infection hypha $(\mathrm{H})$ growing between two cortical cells (C). Vesicles (arrow) are concentrated at the hyphal tip (X 2400). 

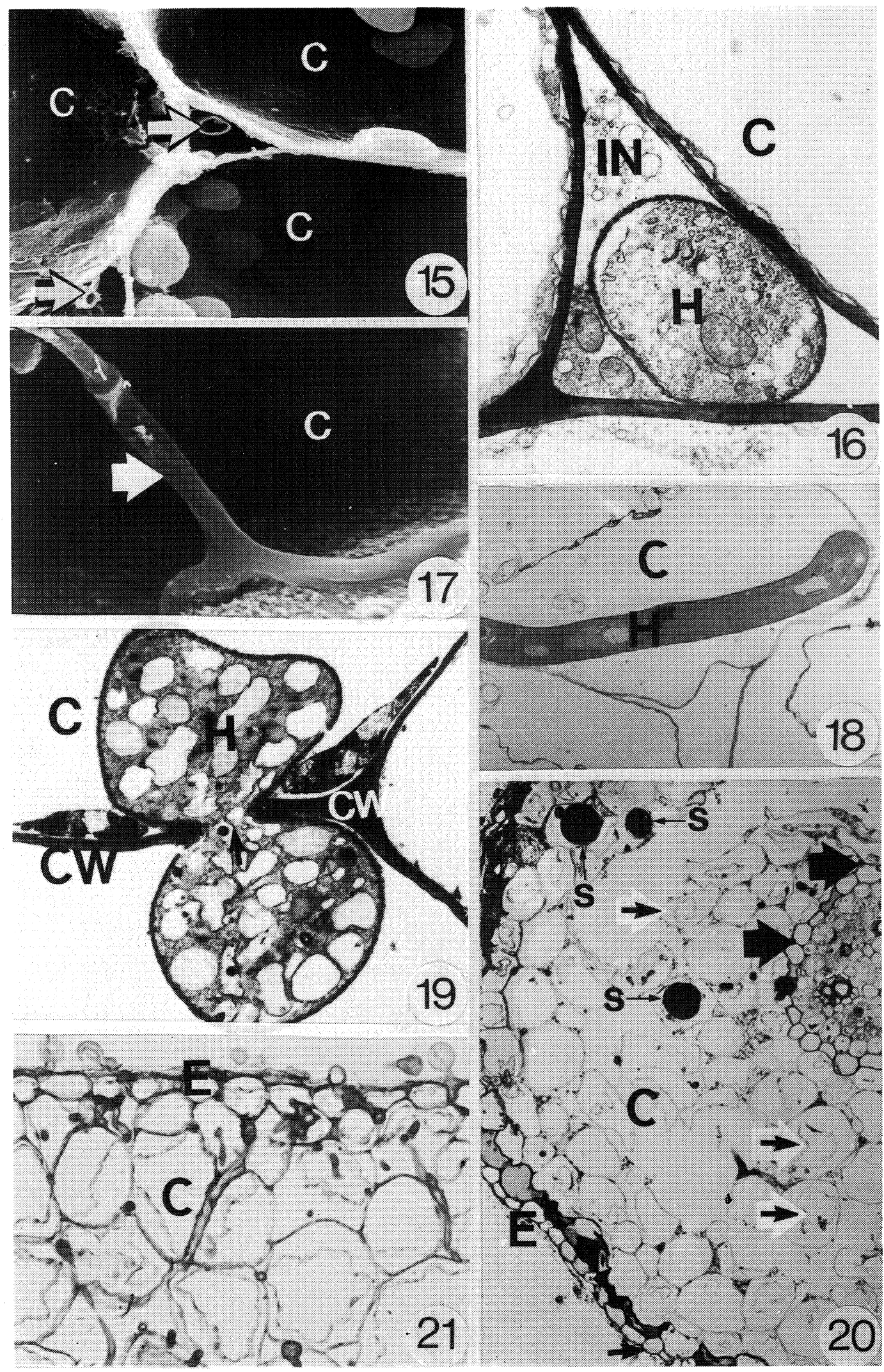

Figs. $15-19$.

Penetration and infection of 99 Richter grapevine roots by Phytophthora cinnamomi. 15. Scanning electron micrograph of an intercellular hypha (arrow) in the intercellular space of cortical cells (C) (X 2 400). 16. Transmission electron micrograph of an intercellular hypha (H) in the intercellular space (IN) of cortical cells (C) (X7 500). 17. Scanning electron micrograph of an intracellular hypha (arrow) in a cortical cell (C) (X 5400 ). 18. Transmission electron micrograph of an intercellular hypha $(\mathrm{H})$ in a cortical cell $(\mathrm{C})(\mathrm{X} 4000)$. 19. Transmission electron micrograph of an intercellular hypha $(\mathrm{H})$ growing from one cortical cell $(\mathrm{C})$ to another. Note the typical constriction of the hypha at the point of cell wall (CW) penetration (arrow) (X7 500). 20. Light micrograph of a transverse section of a root $48 \mathrm{~h}$ after inoculation. The invaded epidermal (E) and cortical (C) cells are disrupted and plasmolysed (small arrows). Invading hyphae are present in the endodermis (large arrows), while spores (S) are visible in the cortical cells (X100). 21. Light micrograph showing disrupted, plasmolysed epidermal (E) and cortical (C) cells (X 160). 
TABLE 1

Number of encysted and germinating zoospores in four consecutive zones extending from the root tips of 99 Richter grapevine.

\begin{tabular}{lc}
$\begin{array}{c}\text { Zone distance }(\mathrm{mm}) \\
\text { from root }\end{array}$ & $\begin{array}{c}\text { Number of encysted and germinating } \\
\text { zoospores }\end{array}$ \\
\hline $0-0,5$ & 42,6 \\
$0,5-1,0$ & 42,6 \\
$1,0-1,5$ & 11,6 \\
$1,5-2,0$ & 6,2 \\
\hline D-value $(P=0,01)$ & 4,2 \\
\hline
\end{tabular}

Germination of cysts commenced within a few minutes of zoospore encystment on the root surface. The single unbranched germ tube appeared as a conical protuberance (Fig. 2) where the cyst made contact with the root surface. The germ tube grew perpendicular to the root surface, and subsequent penetration occurred mostly down the anticlinal walls separating epidermal cells (Fig. 3). Thus an intercellular cleavage was established (Fig. 4). The germ tube sometimes grew along the root surface until a suitable site for penetration was encountered.

Granular material was detected below the zoospore germ tube on the host surface (Fig. 5). Although direct penetration of epidermal cells was observed occasionally (Fig. 6) penetration occurred primarily through the middle lamella of the anticlinal walls of epidermal cells. Swollen germ tubes (Fig. 7) were usually confined to the sites where penetration occurred directly through the epidermal cell wall. The germ tube wall was often thickened at the 2 point of contact with the epidermal cell wall (Fig. 8). Walls of cortical cells adjacent to, and in advance of the penetrating hyphae, were usually hydrolyzed (Fig. 9).

Following germination, zoospore cysts became progressively vacuolated until they were empty (Figs. 10 and 11). After penetration of the host, a thick plug of amorphous material was formed which sealed off the hyphae in the root from the empty cyst and germ tubes (Figs. 12 and 13). Vesicles containing electron-dense material were abundant at the growing tip of the penetrating hyphae (Fig. 14).

Penetration by vegetative hyphae was essentially similar to penetration initiated from zoospores. However, hyphae constricted markedly at the point of penetration. Hyphal cushions were not observed.

Four hours after inoculation the cortex was infected, and intercellular (Figs. 15 and 16) as well as intracellular (Figs. 17 and 18) hyphal development were evident. Typical constriction of hyphae was seen where host cells were penetrated directly (Fig. 19).

Within $48 \mathrm{~h}$ after inoculation hyphae were observed in the endodermis (Fig. 20). Invaded epidermal, cortical and endodermal cells were disrupted and showed signs of plasmolysis (Figs. 20 and 21).

More zoospores of $P$. cinnamomi encysted on and near grapevine roots than further away. Attraction of zoospores by plant roots is well-documented and is attributed to stimulatory chemicals present in the root exudates (Dukes \& Apple, 1961; Zentmyer, 1961; Cunningham \& Hagedorn, 1962; Rai \& Strobel, 1966; Ho \& Hickman, 1967; Khew \& Zentmyer, 1973).

The function and origin of the granular material detected below the zoospore germ tube on the host surface are uncertain. According to Endo \& Colt (1974) other workers have suggested that the granular material acts as an adhesive which attaches the zoospore to the host surface.

Penetration of root tissue occurred more often at the wall juncture of epidermal cells than directly through the host wall. This suggests that the fungus followed the path of least resistance. Swollen germ tubes were observed occasionally where epidermal cells were penetrated directly. This agrees with reports that appressorial formation by the Pythiaceae is inconsistent (Endo \& Colt, 1976). However, variation in appressorium morphology is common, and all structures adhering to host surfaces to achieve penetration, regardless of morphology, are regarded as appressoria by some authors (Emmett \& Parbery, 1975).

The importance of mechanical pressure exerted by pathogens to gain entry into host cells has been emphasized (Kraft, Endo \& Erwin, 1967; Spencer \& Cooper, 1967; Marks \& Mitchell, 1971; Nemec, 1972; Kim, Kantzes $\&$ Weaver, 1974). In the present investigation no evidence was found that epidermal cell walls were indented prior to penetration. Instead, penetration was associated with enzymatic hydrolysis of epidermal cell walls or often with cleavage of the middle lamella of the anticlinal walls of these cells. In infected root tissue, hydrolysis of cortical cell walls was evident. These observations agree with reports that species of Phytophthora and Pythium produce enzymes capable of degrading cell walls in vivo and in vitro (Ashour, 1954; Winstead \& McCombs, 1961; Moore \& Couch, 1968; Turner \& Bateman, 1968).

The role of the plug which seals off the penetration peg and infection hyphae from the empty cyst and germ tube is not yet clear. Possibly, it protects the colonizing hyphae in the root against antagonistic micro-organisms present in the rhizosphere.

Hyphal cushions are prevalent on pine roots penetrated by vegetative hyphae (Marx \& Bryan, 1969). In the present study, grapevine roots were penetrated by hyphae, but hyphal cushions were never observed.

Marx \& Bryan (1969) found that in the absence of sporangial-inducing soil-bacteria, vegetative hyphae of $P$. cinnamomi are an important source of inoculum. Chlamydospores are important survival units of $P$. cinnamomi and, in the absence of a living host, persist for long periods in dead roots and in soil (Zentmyer \& Mircetich, 1966). Reeves (1975) found that chlamydospores are produced over a wide range of moisture regimes, but that sporangia are only formed at the higher moisture levels. Sterne, Zentmyer \& Kaufmann (1977) reported that germination of chlamydospores and growth of a single or several resultant germ tubes can take place at low matric potentials. In the absence of sporangia, the chlamydospore germ tubes which later become hyphae, may also play a role in infection at low matric potentials. Vegetative hyphae may possibly be responsible for the secondary spread of $P$. cinnamomi in the root zones of grapevines.

\section{LITERATURE CITED}

ASHOUR, W. E., 1954. Pectinase productions by Botrytis cinerea and Pythium debaryanum. Trans. Brit. Mycol. Soc. 37, 343-352.

CHEN, D., \& ZENTMYER, G. A., 1970. Production of sporangia by Phytophthora cinnamomi in axenic culture. Mycologia 62, 397 - 402. 
CUNNINGHAM, J. L. \& HAGEDORN, D. J., 1962. Attraction of Aphanomyces euteiches zoospores to peà and other plant roots. Phytopathology 52, 616 618.

DUKES, P. D. \& APPLE, J. L., 1961. Chemotaxis of zoospores of Phytophthora parasitica var. nicotianae by plant roots and certain chemical solutions. Phytopathology 51, $195-197$.

EMMET, R. W. \& PARBERY, D. G. 1975. Appressoria. Annu. Rev. Phytopathol. 13, $147-167$.

ENDO, R. M. \& COLT, W. M., 1974. Anatomy, cytology and physiology of infection by Pythium. Proc. Amer. Phytopath. Soc. 1, 215-223.

HO, H. H. \& HICKMAN, C. J., 1967. Factors governing zoospore responses of Phytophthora megasperma var. sojae to plant roots. Can. J. Bot. 45, 1983 - 1994.

JAMES, N., 1958. Soil extract in soil microbiology. Can. J. Microbiol. 4, 363 - 379.

KHEW, K. L. \& ZENTMYER, G. A., 1973. Chemotactic response of zoospores of five species of Phytophthora. Phytopathology 63, 1511 - 1517.

KIM, S. H., KANTZES, J. G. \& WEAVER, L. O., 1974. Infection of aboveground parts of bean by Pythium aphanidermatum. Phytopathology 64, 373 - 380.

KRAFT, J M., ENDO, R. M. \& ERWIN, D. C., 1967. Infection of primary roots of bentgrass by zoospores of Pythium aphanidermatum. Phytopatholgy 57, 86 90.

MARAIS, P. G., 1978a. Occurrence and control of Phytophthora cinnamomi in South African vineyards. Proc. S. Afr. Soc. Enol. Vitic. 1978, 4- 27.

MARAIS, P. G., 1978b. Pourridé des racines de vigne provoqué par le champignon Phytophthora cinnamomi. Progrés Agric. Vitic. 95, 135 - 140.

MARAIS, P. G., 1979. Situation des porte - greffes resistants á Phytophthora cinnamomi. Bull. de. l'O.I.V. 52, 357 - 376.

MARKS, G. C. \& MITCHELL, J. E., 1971. Penetration and infection of alfalfa roots by Phytophthora megasperma and the pathological anatomy of infected roots. Can. J. Bot. 49,63-67.

MARX, D. H. \& BRYAN, W. C., 1969. Effect of soil bacteria on the mode of infection of pine roots by Phytophthora cinnamomi. Phytopathology 59, 614 619.
MOORE, L. D. \& COUCH, H. B., 1968. Influence of calcium nutrition of pectolytic cellulolytic enzyme activity of extracts of highland bentgrass foliage blighted by Pythium ultimum Phytopathology 58, 833 -838 .

NEMEC, S., 1972. Histopathology of Pythium infected strawberry roots. Can. J. Bot. 50, $1091-1096$.

RAI, P. V., \& STROBEL, G. A., 1966. Chemotaxis of zoospores of Aphanomyces cochlioides to sugar beet seedling. Phytopathology 56, $1365-1369$.

REEVES, R. J., 1975. Behaviour of Phytophthora cinnamomi Rands in different soils and water regimes. Soil. Biol. Biochem. 7, 19 - 24.

REYNOLDS, E. S., 1963. The use of lead citrate at high $\mathrm{pH}$ as an electronopaque stain in electron microscopy. J. Cell. Biol. 17, 208 - 213.

SPENCER, J. A. \& COOPER, W. E., 1967. Pathogenesis of cotton (Gossypium hirsutum) by Pythium species: zoospore and mycelium attraction and infectivity. Phytopathology 57, 1332 - 1338.

SPURR, A. R., 1969. A low-viscosity epoxy resin embedding medium for electron microscopy. J. Ultrastuct. Res. 26, 36 - 43 .

STERNE, R., ZENTMYER, G. A. \& KAUFMANN, M. R., 1977. The influence of matric potential, soil texture and soil amendment on root disease caused by Phytophthora cinnamomi. Phytopathology 67, 1495 -1500 .

TURNER, M. T. \& BATEMAN, D. F., 1968. Maceration of plant tissues susceptible and resistant to soft-rot pathogens by enzymes from compatible host pathogen combinations. Phytopathology 58, $1509-1515$.

VAN DER MERWE, J. J. H., JOUBERT, D. J. \& MATTHEE, F. N., 1972. Phytophthora cinnamomi root rot of grapevines in the Western Cape. Phytophylactica 4, $133-136$.

WINSTEAD, N. N. \& McCOMBS, C. L., 1961. Pectinolytic and cellulolytic enzyme production by Pythium aphanidermatum. Phytopathology 51, 270 273.

ZENTMYER, G. A., 1961. Chemotaxis of zoospores for root exudates. Science 133, 1595 - 1596.

ZENTMYER, G. A. \& MIRCETICH, S. M., 1966. Saprophytism and persistence in soil by Phytophthora cinnamomi. Phytopathology 56, 710 - 712. 